\title{
IFRS For U.S. Companies
}

\author{
Obeau Persons, Rider University, USA
}

\begin{abstract}
Growing acceptance of the International Financial Reporting Standards (IFRS) worldwide and recent actions of the Securities Exchange Commission (SEC) indicate that IFRS could soon become a body of accounting principles generally accepted in the United States of America (U.S.). It is, therefore, very crucial that investors, preparers, auditors, educators and regulators are aware of how this imminent change would affect them. This commentary article addresses this timely issue by critically examining: (1) potential benefits of allowing U.S. firms to adopt IFRS, (2) necessary changes related to the IASB and IFRS, and (3) necessary changes to the U.S. financial reporting infrastructure. It also raises specific concerns that the SEC should consider.
\end{abstract}

Keywords: IFRS, IASB, Roadmap, U.S. financial reporting, GAAP reconciliation

\section{INTRODUCTION}

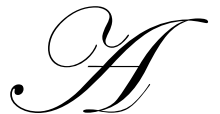

s product, services, and capital markets have become more and more global, firms are looking for a global standard of efficiency in all their operations. Such market pressures are argued to be causing convergence to the most efficient way of organizing global organizations, such as the reorganization of elements of national infrastructure including markets, regulatory regimes, financial reporting and auditing, and corporate governance. Such evidence in the area of financial reporting is the worldwide convergence toward the use of IFRS as set by the International Accounting Standards Board (IASB). The European Union (EU), Australia and South Africa have required their publicly listed companies to use IFRS to prepare their consolidated financial statements since January 1, 2005. New Zealand has applied such requirement to its listed companies since January 1, 2007. ${ }^{1}$ Chile and Brazil will impose such requirement on their listed companies in 2009 and 2010 , respectively. Canada, India and South Korea plan to do the same at the beginning of 2011. Malaysia plans to fully converge its standards with IFRS by January 1, 2012.

In response to this worldwide financial reporting convergence toward IFRS, the Securities Exchange Commission (SEC) recently took its first step toward embracing the IFRS by allowing foreign companies to file financial statements using IFRS without reconciling net income and stockholders' equity to U.S. generally accepted accounting principles (GAAP) for fiscal year ending on or after November 15, 2007. The SEC hopes this move will attract more foreign stock listing to U.S. exchanges. An even more important move by the SEC came in August 2007 when it issued (proposed) Concept Release on Allowing U.S. Issuers to Prepare Financial Statements in Accordance with International Financial Reporting Standards (the Concept Release). After the comment period of the Concept Release ended in November 2007, the SEC held two roundtables to solicit additional comments in December 2007. The consensus of the roundtable participants favors an orderly move to IFRS (from U.S. GAAP) with a transitioning timetable ending on a specific date.

Then in August 2008, the SEC proposed a roadmap that could lead to the use of IFRS by large accelerated filers for fiscal years ending on or after December 15, 2014, followed by accelerated filers for years ending on or after December 15, 2015, and smaller companies for years ending on or after December 15, 2016, if specified milestones are achieved. ${ }^{2}$ The SEC will make the decision in 2011 on whether to require all of its registrants to use IFRS based upon the progress of these milestones including funding of the IASB, accounting education and IFRS data tagging. The SEC's proposal would also allow at least 110 very large U.S. multinational companies to use the IFRS at the end of fiscal years ending after December 15, 2009. 
Because this transition would be one of the greatest changes in the U.S. financial reporting history, it is highly important that investors, preparers, auditors, educators and regulators are aware of how the change would affect them. This study addresses this timely issue by critically examining: (1) potential benefits of allowing U.S. firms to adopt IFRS, (2) necessary changes related to the IASB and IFRS, and (3) necessary changes to the U.S. financial reporting infrastructure.

\section{POTENTIAL BENEFITS OF ALLOWING U.S. FIRMS TO ADOPT IFRS}

Over 110 jurisdictions now either require or permit the use of IFRS for the preparation of financial statements by their listed companies. ${ }^{3}$ Therefore, U.S. companies will find it easier and less costly to access foreign capital markets which require or permit the use of IFRS rather than U.S. GAAP. The use of IFRS would also eliminate dual reporting of U.S. companies which are subsidiaries of foreign parents that use IFRS, and U.S. parents with subsidiaries based in jurisdictions that require the use of IFRS for local regulatory or statutory filings. These companies would not have to maintain two sets of financial reports, leading to substantial reduction in recordkeeping costs. Additionally, it should enhance comparability of U.S. companies' financial results with those of foreign competitors which use IFRS. This would benefit investors worldwide since they would not have to incur time, costs and effort to understand complex rule-based U.S. GAAP. As a result, this would lower the cost of capital of U.S. companies, and possibly enhance capital market efficiency and worldwide economic growth. The transition to IFRS would also enable easier movement of auditors and accountants across borders. Furthermore, the move to IFRS may reduce financial restatements especially those related to highly technical rules-based standards such as leases and financial instruments. Lastly, it may reduce the probability of another Enron accounting debacle wherein financial instruments and business transactions were designed to meet the technical requirements of rule-based U.S. GAAP while violating the intent.

\section{NECESSARY CHANGES RELATED TO THE IASB AND IFRS}

The SEC should seek international cooperation to identify and implement changes necessary to sustain the IASB as an independent setter of high-quality accounting standards. The following changes should be completed before the transitioning period commencement.

\section{Sufficient and Stable Funding and Staffing Levels of the IASB}

Current levels of funding and staffing are not adequate if IFRS should become the single set of global accounting standards. Current funding sources also appear unstable and give rise to an independence concern. ${ }^{4}$ In particular, The International Accounting Standards Committee Foundation (IASCF) has financed IASB operations mainly through voluntary contributions from companies, accounting firms, international organizations and central banks. These sources of funding appear inconsistent with the mechanisms envisioned in Section 108 of the Sarbanes-Oxley Act. A global consortium, perhaps led by the SEC and the International Organization of Securities Commissions (IOSCO) with collaboration with the Trustees of IASCF, should try to establish a funding mechanism that provides adequate resources while protecting independence. In deed, in June 2006, the IASCF Trustees agreed that its funding approach should be governed by four elements: (1) broad-based including all major participants in the world's capital markets to ensure diversification of sources, (2) compelling by including official support from relevant regulatory authorities to minimize free riding, (3) open-ended and not contingent on any particular action that would infringe on the independence of the IASC Foundation and the IASB, and (4) country-specific funding burden proportionately shared by the major economies of the world on the basis of Gross Domestic Product. ${ }^{5}$

\section{Composition, Independence and Monitoring of the IASB}

Currently four out of 14 IASB members are from the U.S. Given that the U.S. is the world largest economy and home of the world largest capital market, there might be a need to increase the U.S. representation on the IASB. The constitution of IASCF, which oversees the IASB, has recently been amended to allow for an expanded size of the IASB and a better monitoring of the IASB. In particular, a new monitoring board with the SEC Chairman as a member was formed to oversee the IASCF trustees and to hold them publicly accountable in the development of international accounting standards. ${ }^{6}$ This amendment makes the IASB structure in compliance with 
the U.S. Securities Acts requirement that the SEC has an oversight power over the professional body that sets accounting standards for use by U.S. public companies. It remains to be seen whether this new monitoring board could effectively shield the IASB from any political pressure similar to what happened in October 2008 when the IASB completely neglected its due process and changed the fair value accounting in just one day due to the threat from the EU. ${ }^{7}$ Such IASB action greatly tarnished its reputation as an independent standards setting body.

\section{The Need to Eliminate Cross-Jurisdiction Differences in terms of IFRS Endorsement, Interpretation and Enforcement Processes}

Various jurisdictions, including the European Union, have retained the power to endorse (and adapt as seen appropriate) each IFRS after it is issued by the IASB. These jurisdictions need to make their view known during the IASB due process rather than after the standards are issued. Jurisdiction-specific interpretation of IFRS should also be deterred. The IASB implementation guidance should be the only authoritative document for interpreting and applying IFRS. Additionally, an extensive cooperation and commitment of securities regulators worldwide, most likely through the IOSCO, is needed to assure consistent application and enforcement of IFRS across jurisdictions.

\section{NECESSARY CHANGES TO THE U.S. FINANCIAL REPORTING INFRASTRUCTURE}

\section{Changes in Financial Reporting Culture}

Preparers of financial statements and their auditors must bring about changes in the U.S. financial reporting culture by exercising more professional judgment as opposed to the reliance on detailed bright-line guidance prevalent under current rules-based U.S. GAAP. This is probably the most challenging change because the demand for bright-line guidance comes from preparers and auditors, and the Financial Accounting Standards Board (FASB), which sets U.S. GAAP, typically honors this demand. On the other hand, the IASB uses a principle-based approach by relying on the Framework for the Preparation and Presentation of Financial Statements to develop and revise IFRS. The Framework, which establishes the objective, the qualitative characteristics and the elements (including definition, recognition, and measurement) of financial statements, emphasizes economic substance over form. In order to sustain IFRS as principles-based standards and to promote the exercise of judgment by preparers and auditors, the IASB generally issues less-detailed implementation guidance. Therefore, in absence of any relevant guidance and other IFRSs dealing with similar or related issues, preparers and auditors need to refer to the Framework in applying any specific IFRS, and in dealing with topics that have not yet been addressed in IFRS. Preparers and auditors must refrain from asking the SEC to expand interpretation and implementation guidance of IFRS. Absence of such change may result in a possible U.S. variant of IFRS.

\section{IFRS Overriding Principle of Fair Presentation}

Compliance with IFRS generally ensures that financial statements would present fairly the financial position, financial performance and cash flows of an entity. However, in a rare circumstance when preparers conclude that compliance with the requirement of a standard or interpretation would be so misleading that it would conflict with the objective of financial statements set out in the Framework, IAS 1, Presentation of Financial Statements, requires departing from that requirement with extensive disclosures in the notes to financial statements. U.S. GAAP does not have such overriding principles available to preparers. ${ }^{8}$ This means that, in applying IFRS, preparers should always critically think whether the accounting treatments would produce financial results that faithfully represent the underlying economic substance of business transactions and events, as opposed to the cookbook approach of rule-based GAAP.

\section{Changes in Regulations and Contractual Obligations}

Accounting-based regulations and contracts likely need to be adjusted because net income and assets under IFRS are typically larger than those under U.S. GAAP. IFRS allows revaluation of plant assets such as land and building which generally appreciate in fair market value while U.S. GAAP prohibits the revaluation. IFRS also requires capitalization of development costs while U.S. GAAP requires expensing the costs. IFRS does not allow LIFO which is the most commonly used inventory method among U.S. companies because of its substantial tax 
saving. Below are examples of accounting-based regulations and contracts which will likely be affected by the transition to IFRS, and therefore, would need to be modified.

A. Banking regulations which use accounting information as a basis for monitoring the safety and soundness of financial institutions.

B. Governmental contracting which uses accounting numbers as a basis for defining requirements.

C. Debt contracts which rely on amounts in the financial statements to assess the firm's liquidity and solvency and to determine whether the firm has violated any debt covenant requirements.

D. Compensation contracts which tie manager compensation to profitability of the firm.

E. Transfer pricing documentation as well as Advanced Transfer Pricing Agreements and tax rulings that may have been based on U.S. GAAP.

F. The magnitude of utility rates set by states based on profitability and asset base of utility companies.

G. The SEC accounting and disclosure requirements. Regulation S-X requirements provide a substantial degree of specificity regarding the items to be presented on the balance sheet and income statement, whereas IFRS does not provide any specific convention as to the format and content of the financial statements. Should these requirements be modified to be in line with the principles-based basis of IFRS? In addition, Regulation S-X disclosure requirements for investment companies may need modification if investment companies are to prepare IFRS financial statements. Changes must also be made to Regulation $\mathrm{S}-\mathrm{K}$ disclosure requirements for non-financial statement items (such as disclosure of off-balance sheet arrangements) which make reference to specific U.S. GAAP pronouncements.

H. The U.S. Internal Revenue Service (IRS) regulations regarding the LIFO tax conformity requirement will have to be repealed because IFRS does not allow LIFO.' Any attempt to completely disallow LIFO for tax filing purpose will likely face much opposition by U.S. companies. The IRS regulations concerning a corporation's alternative minimum taxable income may also need changes since the income is increased by the difference between net income reported to shareholders (as adjusted) and its alternative minimum taxable income.

\section{Challenges for Preparers of Financial Statements}

The transition to IFRS is not just an accounting exercise, but an enterprise-wide effort that requires sponsorship and support of top management. Preparers will need to train their accounting/finance personnel to make them knowledgeable of relevant IFRS. Because IFRS requires more judgment calls than U.S. GAAP, preparers must establish procedures to assure consistent judgment across the entire organization including all foreign subsidiaries. Significant information system changes would also be required especially for financial institutions which rely on accounting numbers on the financial statements to monitor loan performance and financial instrument risk. One of major information system challenges is the issue of GAAP reconciliation. The SEC laid out two options in its proposal: one calling for the traditional IFRS first-time adoption reconciliation, the other requiring that step plus an ongoing unaudited reconciliation of the financial statements from IFRS to U.S. GAAP. The second option is clearly a more costly approach. A well-run company would want to address that by running parallel or dual systems.

U.S. companies may also want to start converting to IFRS for statutory reporting purposes for subsidiaries in those countries that permit the use of IFRS. This could provide an opportunity to develop a multiyear strategy and a detailed roadmap for conversion to IFRS on a consolidated basis. This roadmap could encompass a broader finance transformation project that would increase standardization of financial reporting across all dimensions, centralization of process, and realization of economies of scale. ${ }^{10}$ In addition, an assessment and reporting of the effectiveness of internal controls over financial reporting would likely need to be adjusted to encompass the preparation of financial information in accordance with IFRS. Furthermore, companies need to communication with users of financial statements at least one year before the transitioning date regarding: (1) why there is such transition, (2) brief discussion about the IASB and IFRS particularly their principles-based approach, (3) potential benefits of using IFRS, (4) what the company has done and plans to do to ensure a smooth transition to IFRS, and (5) potential impact on important financial-statement amounts such as net income, inventory, plant assets, total assets, liabilities, and stockholders' equity. 
The transition to IFRS will also potentially impact a company's tax provision and effective tax rate, income tax related disclosures, global cash tax obligations, international tax planning, state and local taxes, transfer pricing determinations, and processes, control and systems for tax reporting and compliance. The transition will require an analysis of each new accounting policy for its related tax implications, including a determination as to whether it is permissible or advisable to conform the related tax method of accounting to the new book accounting method. U.S. firms may also need to change the way they account for and disclose uncertain tax positions as required by FASB Interpretation No. 48, Accounting for Uncertainty in Income Taxes (FIN 48) because the IASB has indicated that its current intention is not to adopt the recognition, measurement and disclosure requirements of FIN 48.

\section{Challenges for Accounting Firms}

The use of IFRS would affect the accounting firms that are engaged in auditing a U.S. company's financial statements and to report on the effectiveness of its internal controls. Because U.S. auditors have less experience with IFRS than with U.S. GAAP, in the short-term, accounting firms may encounter challenges in establishing quality control policies and procedures to assure that their personnel possesses sufficient knowledge to perform audits of IFRS financial statements. Additional auditing guidance may still be necessary for auditors to appropriately address issues related to the transition to reporting on IFRS financial statements. For the U.S. accounting firms that are member of global audit networks, systems of quality control need to foster the high quality and consistent application of IFRS across national borders. Because IFRSs are principles-based with little specific guidance on compliance, auditors will need to understand the economics and the intent of a specific transaction in order to apply an appropriate accounting treatment. Many are concerned that auditors will likely require U.S. companies to make more disclosure such as in the determination of whether technology development costs have met certain criteria (e.g., the technical and economic feasibility) for capitalization. This increase in disclosure may lead to a revealing of trade secrets which can be detrimental to the competiveness of a company. ${ }^{11}$

\section{Challenges for Users of Financial Statements}

Users of financial statements especially financial analysts need to be educated and trained to understand IFRS and major differences between IFRS and U.S. GAAP. There are several online information sources about IFRS including www.ifrs.com, www.iasplus.com, www.ey.com/ifrs, and www.kpmgifrsinstitute.com. In addition, researchers who utilize time-series analysis which covers the transitioning period to IFRS needs to be aware of a potential upward bias in the analysis results since IFRS amounts of assets, net income, and stockholders' equity tend to be higher than those under U.S. GAAP.

\section{Challenges for Accounting Educators}

Substantial changes in accounting education would be required. Educators should now try to incorporate IFRS into all financial accounting and auditing courses starting from the introductory level up through advanced level courses. Because educators typically rely on textbooks in terms of course coverage, the publishers must incorporate IFRS into all financial accounting and auditing textbooks. The textbook authors and publishers need to highlight not only the accounting treatment differences between IFRS and U.S. GAAP but also the importance of critical thinking in an exercise of judgment, which is a crucial aspect of the principles-based IFRS. Such critical thinking should be incorporated as much as possible into the textbooks, perhaps through real-world case studies.

\section{Changes in Testing and Certification Requirements}

The content of the Financial Accounting \& Reporting (FAR) section of the CPA exam needs to include IFRS. In deed, the American Institute of Certified Public Accountants (AICPA) has recently planned to include questions related to IFRS in Area I topics (Conceptual Framework, Standard Setting \& Regulatory Reporting Requirements) of the Financial Accounting and Reporting (FAR) section. If IFRS becomes generally accepted in the U.S., the AICPA plans to expand IFRS testing in all three FAR topics areas related to private-sector entities. ${ }^{12}$ Additionally, any professions such as actuaries and valuation experts, who may be engaged by companies to assist in measuring assets and liabilities, need to integrate IFRS into their training materials, publications, testing and certification programs. 


\section{Roles of the SEC and the FASB}

Roles of the SEC and the FASB as the current accounting-standard setting authority need to be redefined. The SEC (not to mention U.S. companies) would not be able to influence the IASB as much as it does with the FASB since the IASB is a global standard setting body representing interests of many countries, and is not under a direct oversight of the SEC as the FASB. The SEC must try to refrain from unilaterally interpreting or stating its view on a specific IFRS accounting issue that causes significant difficulties in practice without consultation with the IASB. Similar to other jurisdictions, the U.S. might retain the FASB to develop standards for private companies and not-for-profit entities which do not participate in the global capital market. The FASB might help educate U.S. constituents in the application of IFRS or provide the IASB with research support such as identifying U.S. issues as candidates for IASB action.

\section{Compatibility between U.S. and IFRS Versions of XBRL}

The SEC mandate of public company reporting in XBRL (Extensible Business Reporting Language) will be phased in over two years with the largest public companies, estimated at 500 companies, required to comply with the mandate starting with their June 15, 2009 quarter. Steps need to be taken to assure compatibility between U.S. GAAP and IFRS versions of XBRL, otherwise the transition to IFRS will be complicated by system incompatibility and costly redesign. The IFRS list of tags is not as complete as the U.S. GAAP list, and is to be improved so as to provide the level of detail required by the SEC.

\section{U.S. Litigation Environment}

Litigation proneness environment in the U.S. will necessitate thorough documentation and transparent disclosure of how preparers and their auditors make specific judgment. The judgment will need to be supported by appropriate contemporary analysis. The court system, trial lawyers, and investors should realize that applying principles-based IFRS will likely produce a broader range of acceptable amounts because different individuals could arrive at different conclusions regardless of how well-meaning their intent and judgment process are.

\section{CONCLUDING REMARKS}

Because the transition to IFRS will have pervasive effects on virtually all elements of the U.S. financial reporting infrastructure, the SEC should definitely not act in haste, and should give thorough consideration to the design of the transition process to IFRS. There are also other concerns that the SEC should consider. The FASB and the IASB are currently conducting several joint convergence projects, some of which may take several years to complete. ${ }^{13}$ If the SEC requires U.S. public companies to switch to IFRS, would this jeopardize the role and the views of the FASB in carrying out these joint projects because the FASB will no longer be the standard setting body for U.S. public companies? What would happen if the FASB's views are in conflict with the IASB's view? It seems that the main motivation of the IASB to improve IFRS and to conduct joint convergence projects with the FASB is to induce the SEC to allow U.S. companies to use IFRS to prepare financial statements. Therefore, an even more important concern is: would the IASB have any incentive in the future to improve IFRS if the SEC mandates U.S. companies to use IFRS?

On the other hand, the SEC may end up asserting an undue influence over the IASB because the U.S. will likely become the major contributor of the IASB funding if Gross Domestic Product is used as the required funding measure. The SEC has already stated in the Concept Release that the SEC may find it necessary to state its view on a particular IFRS accounting issue that causes significant difficulties in practice, and neither the IASB nor International Financial Reporting Interpretations Committee (IFRIC) has addressed the issue. Although the SEC also states that it could subsequently refer the accounting issue to the IASB or IFRIC for resolution, the IASB or IFRIC may end up adopting the SEC view if such view should become generally accepted industry practices in the U.S. Such substantially more U.S. influence over the IASB could alienate some constituents such as the EU which has already expressed its concern over the U.S.-rule-based approach of IAS 39, Financial Instruments: Recognition and Measurement, and its inability to affect the IASB agenda, which is currently dominated by joint convergence projects with the FASB. 


\section{AUTHOR INFORMATION}

Obeua S. Persons is an Associate Professor of Accounting at Rider University in Lawrenceville, New Jersey, U.S.A. She earned her B.A. from Chulalongkorn University, Bangkok, Thailand, and Master of Accountancy and $\mathrm{Ph} . \mathrm{D}$ in accounting from the University of Texas at Austin. Her teaching interests include financial, managerial and international accounting. Her research interests include corporate governance, executive compensation, international accounting, and financial reporting. Her publications have appeared in Review of Accounting \& Finance, Journal of Business Ethics, Journal of Business and Economic Studies, Multinational Finance Journal, Managerial Finance, Journal of Business Research, Research in Accounting Regulation among others.

\section{ENDNOTES}

1. Australia and New Zealand have adopted national standards that they describe as IFRS-equivalents.

2. See the SEC proposed rule, Roadmap for the Potential Use of Financial Statements Prepared in Accordance with International Financial Reporting Standards by U.S. Issuers, at www.sec.gov/rules/proposed/2008/338982.pdf. The roadmap was published on November 14, 2008. Large accelerated filers include companies with worldwide market value of voting and non-voting common equity held by non-affiliates of $\$ 700$ million or more. Accelerated filers include companies with worldwide market value of $\$ 75$ million or more.

3. See http://www.iasplus.com/country/useias.htm.

4. Nicolas Veron discusses the funding problems and potential threat to independence in more detail in "The Global Accounting Experiment" (Bruegel Blueprint Series, Vol. II, 2007), p. 39-40.

5. See http://www.iasb.org/About+Us/About+the+Foundation/Future+Funding.htm

6. The amendment to the IASCF constitution calls for an expansion of board members to 16 from 14 by 2012 with a geographical requirement that four members come from each of Asia, Europe and North America, one from each of Africa and South America and two from any region. It also established a new Monitoring Board that would be composed of the heads of the U.S. Securities and Exchange Commission, World Bank, European Commission, International Monetary Fund, International Organization of Securities Commissions and Japan Financial Services Agency. The Monitoring Board would have the responsibility of approving the selection of IASCF Trustees. The Trustees would also report to the Monitoring Group regularly to enable it to address whether and how the Trustees are fulfilling their role set out in the Constitution. The Monitoring Board should enhance the IASCF "transparency and public accountability" without "impairing the independence of the standard-setting process," according to an IASCF statement.

7. The IASB amended IAS 39, Financial Instruments: Recognition and Measurement, to allow the retrospective (back to July 1, 2008 before the financial market turmoil) reclassification of certain financial instruments so as to lessen the negative impact on earnings. The EU threatened that it would legislate the change if the IASB refused to do it.

8. Rule 203 of the AICPA's Code of Professional Conduct has such overriding principle available to auditors. However, auditors have never invoked this rule for public companies because it is highly doubtful whether the SEC will accept such an auditor report.

9. The LIFO conformity rule requires a firm to use LIFO for financial reporting if it uses LIFO for tax filing. Congress is considering repealing LIFO and allowing firms to spread the effect of the change from LIFO over a longer period than four years allowed by current law.

10. See Journal of Accountancy, October 2008, 'Profession Reacts to IFRS Plan' News Analysis, p. 20-22.

11. Cole, Marine. 'Global Accounting Rules Could Reveal Trade Secrets', Financial Week, October 26, 2008, www.financialweek.com/apps/pbcs.dll/article?AID=/20081026/REG/810242220.

12. Coverage of IFRS on the CPA Exam is expected by the year 2012, but possibly sooner, as the AICPA Examinations Team is now seeking professionals with solid skills and knowledge in IFRS to write multiple choice questions on IFRS.

13. Although both boards aim at publishing final standards of 15 out of 16 convergence projects by 2011, when the SEC is supposed to decide whether to mandate IFRS for U.S. companies, it is truly challenging for the boards to meet such highly aggressive time-table. 


\section{NOTES}

